\title{
Tenascin-C promotes bladder cancer progression and its action depends on syndecan-4 and involves NF-KB signaling activation
}

\author{
Zhenfeng Guan ${ }^{1,2}$, Yi Sun ${ }^{1}$, Liang Mư ${ }^{3}$, Yazhuo Jiang ${ }^{1}$ and Jinhai Fan ${ }^{2^{*}}$ (i)
}

\begin{abstract}
Background: Bladder Cancer ( $\mathrm{BCa}$ ) is a severe genitourinary tract disease with an uncertain pathology. Increasing evidence indicates that the tumor microenvironment plays a decisive role with respect to cancer progression, and that this is driven by tumor cell interactions with stromal components. Tenascin-C (TN-C) is an important extracellular matrix (ECM) component, which has been reported to be involved in other types of cancer, such as breast cancer. The expression of TN-C in BCa tissue has been reported to be positively associated with the BCa pathological grade, yet the presence of urine TN-C is considered as an independent risk factor for $\mathrm{BCa}$. However, the role of TN-C in BCa progression is still unknow. Thus, the object of the present investigation is to determine the role of TN-C in BCa progression and the involved mechanism.
\end{abstract}

Methods: In this study, expression of TN-C in BCa tissue of Chinese local people was determined by IHC. Patients corresponding to tumor specimens were flowed up by telephone call to get their prognostic data and analyzed by using SPSS 19.0 statistic package. In vitro mechanistic investigation was demonstrated by QT-qPCR, Western Blot, Plasmid transfection to establishment of high/low TN-C-expression stable cell line, Boyden Chamber Assay, BrdU incorporation, Wound Healing, laser scanning confocal microscopy (LSCM) and ELISA.

Results: TN-C expression in BCa tissue increases with tumor grade and is an independent risk factor for BCa patient. The in vitro investigation suggested that $\mathrm{TN}-\mathrm{C}$ enhances $\mathrm{BC}$ c cell migration, invasion, proliferation and contributes to the elevated expression of EMT-related markers by activating NF-kB signaling, the mechanism of which involving in syndecan-4.

Conclusions: Expression of TN-C in BCa tissues of Chinese local people is increased according to tumor grade and is an independent risk factor. TN-C mediates BCa cell malignant behavior via syndecan-4 and NF-KB signaling. Although the mechanisms through which syndecan-4 is associated with the activation of NF-KB signaling are unclear, the data presented herein provide a foundation for future investigations into the role of TN-C in BCa progression.

Keywords: Bladder cancer, Tenascin-C, Syndecan-4, progression, NF-kB

*Correspondence: fanjinhai@xjtu.edu.cn

${ }^{2}$ Department of Urology, The First Affiliated Hospital of Xi'an Jiaotong University, 277 Yanta West Road, Xi'an 710061, People's Republic of China Full list of author information is available at the end of the article

\section{Background}

Bladder cancer (BCa) accounts for $90-95 \%$ of urothelial carcinomas and is the most common urinary tract malignancy [1]. Almost $80 \%$ of $\mathrm{BCa}$ cases are initially diagnosed as non-muscle invasive BCa (NMIBC), which has 
a better prognosis; however, some of these tumors progress to muscle invasive BCa (MIBC). Even with surgical interventions, $30 \%$ of $\mathrm{BCa}$ cases become invasive [2] and are thus associated with a worse patient prognosis [3]. The remaining $20 \%$ of $\mathrm{BCa}$ cases are MIBC at initial diagnosis and have a less favorable prognosis, as $5 \%$ of patients have metastatic $\mathrm{BCa}$ [2]. The complete resection of all tumor tissue by transurethral bladder tumor resection (TURBT) is recommended for NMIBC, followed by chemotherapeutic instillation [4]. However, for specific types of BCa, such as T1G3 or carcinoma in situ (CIS), specific treatments are available. Radical cystectomy (RC) with extended lymphadenectomy is considered the standard treatment for MIBC [2], followed by cisplatinbased adjuvant chemotherapy. Two different pathological pathways [5-7] are considered to contribute to MIBC and this is responsible for the different prognoses between initially diagnosed MIBC and MIBC that is derived from NMBIC [8]. Therefore, improving our understanding of the mechanisms through which $\mathrm{BCa}$ progression occurs is warranted in order to establish more effective therapies for $\mathrm{BCa}$.

The tumor microenvironment differs from normal tissue [9-11] and contributes to cancer progression. There is an interplay between cancer cells and stromal components, such as fibroblasts, macrophages and fibronectin, and the initiation of fibrosis is considered to be associated with tumor recurrence, drug-resistance and poor prognosis $[10,12-14]$. As a vital component of the extracellular matrix $(E C M)$ in the tumor mass, tenascin-C $(\mathrm{TN}-\mathrm{C})$ may have multifaceted and complicated roles in tumor progression.

TN-C is large $(\sim 300 \mathrm{kDa})$ as an intact monomer and $\sim 1800 \mathrm{kDa}$ when assembled as a hexamer [15]. Following initial identification in gliomas in $1980 \mathrm{~s}$ [16], $\mathrm{TN}-\mathrm{C}$ has since been found to be expressed in head and neck squamous cell carcinoma, breast [17], prostate [18], thyroid [19], pancreatic [20] cancers, melanoma [21], gastric cancer [22] and osteosarcoma [23]. In the majority of these cancers, TN-C is considered to act as a tumor promoter and is associated with a worse prognosis. TN-C is considered to operate in the surrounding tumor microenvironment by binding to its receptor, annexin II [24, 25 ] or its co-receptor, syndecan- $4 / \alpha 5 \beta \quad 1$ [26-29], causing the loss of focal adhesions and mitogenesis, and increasing cell migration [30, 31]. However, the mechanisms underlying its binding to other receptors and initiating subsequent functions have not yet been established [32-34].

Four syndecan family members are found in mammals; among these, three (syndecan-1, 2 and 3) have a restricted tissue distribution. Syndecan-4 is expressed ubiquitously and is a member of the membrane-intercalated proteoglycans $[35,36]$. Binding to fibronectin within two independent sites with syndecan -4 and $\alpha 5 \beta 1$ is key to the homeostasis of normal tissue [37], and involves the activation of downstream signals related to cytoskeletal organization and cell proliferation. $\mathrm{TN}-\mathrm{C}$ has been reported to compete with the binding site of fibronectin with syndecan- 4 , and this interaction with syndecan-4 partially abrogates the effects of this co-receptor, as well as attenuates the interaction of syndecan- 4 with fibronectin, enhancing tumor cell malignancy. This process also includes FAK and Rho signaling [37].

The activation of NF- $\mathrm{KB}$ signaling, manifested by the nuclear translocation of p65 [38-40], has been demonstrated with immunohistochemical (IHC) staining in $\mathrm{BCa}$ tissues and this has been reported to be positively associated with tumor progression. In addition, epithelialmesenchymal transition (EMT) is another aspect of this signaling [41, 42], promoting BCa malignancy. Previous studies have suggested that $\mathrm{TN}-\mathrm{C}$ is crucial for cancer progression [15] and urinary TN-C may be a useful biomarker of BCa progression [43-45].

The present study aimed to investigate the role of TN-C in $\mathrm{BCa}$ and elucidate the underlying mechanisms. In the present study, IHC analysis revealed that the expression of TN-C was significantly increased according to tumor grade. Further in vitro mechanistic analyses revealed that $\mathrm{TN}-\mathrm{C}$, as an ECM component, activated NF- $\mathrm{kB}$ signaling by binding with syndecan-4 to promote tumor progression. Although the mechanisms through which syndecan-4 activates NF- $\mathrm{kB}$ signaling remain unknown, the present study preliminarily clarified the mechanisms of $\mathrm{TN}-\mathrm{C}$ in the process of $\mathrm{BCa}$ progression, as well as the potential signaling pathways involved. This provides an avenue for further research and may aid in the development of targeted drug design.

\section{Methods}

\section{Tissue preparation and patient follow-up}

BCa tissue samples $(n=57)$ were obtained from the Department of Urology, the First Affiliated Hospital of Xi'an Jiaotong University from Feb, 2010 to Aug, 2016 (32 males; age range, 39-78 years; mean age, $63.7 \pm 7.5$ years, Table 1). Pathological grading was performed by three independent hospital pathologists, and 15, 18 and 24 samples of grade I, II and III were noted, respectively, all of which were transitional cell carcinomas. Samples were fixed in $4 \%$ formalin and embedded in paraffin.

To assess TN-C expression and its association with tumor grade, $\mathrm{TN}-\mathrm{C}$ and survival time were assessed, and the patients who provided the tumor samples were contacted by telephone. The survival data exhibited a normal distribution, as demonstrated by the Shapiro-Wilk test. The present study was approved by the Ethics Committee 
Table 1 Patient Cohort Characteristics of the Present Study

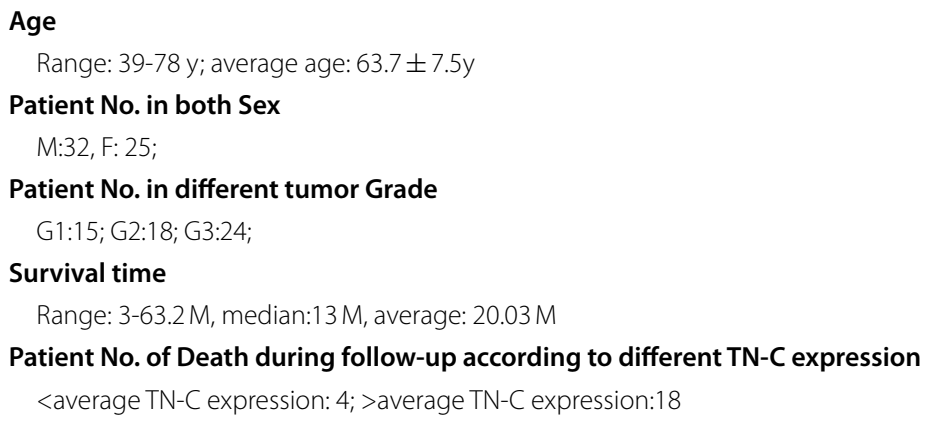

of Xi'an Jiaotong University and all patients involved provided signed informed consent.

\section{IHC staining of TN-C in BCa tissues}

IHC staining was performed using a Dako Autostainer Plus system (Dako; Agilent Technologies, Carpinteria, $U S A)$. Tissues were pre-treated strictly according to the requirements of the manufacturer of the Dako Autostainer Plus system, including de-paraffinization and rehydration, and were subjected to 5-min pressure-cooking antigen retrieval, 15-min endogenous enzyme blocking, 60-min primary antibody (TN-C antibody, 1:300. cat: Sc-25,328; Santa Cruz Biotechnology, Inc., Texas U.S.A.) incubation at room temperature and a 30-min incubation at room temperature with Dako Cytomation EnVision-HRP reagent rabbit antibodies (1:200; Dako; Agilent Technologies, Carpinteria, USA). Signals were measured according to substrate hydrogen peroxide using DAB as a chromogen followed by hematoxylin counterstaining. Negative controls were prepared by omitting the primary antibody. Stained (brown) cells were quantified by counting the positive cells $\times 100 /$ total cells in 10 random microscopic (Olympus, Japan) $(\times 400)$ fields in each section.

\section{Cells and cell culture}

The human BCa cell lines, 5637, T24, RT4, J82 and UM-UC-3, were obtained from ATCC (Manassas, VA, USA) with $253 \mathrm{~J}$ as an exception, which was a gift from Professor Jer-Tsong Hsieh. RPMI-1640 (cat. no.31870082 for 5637 cells) and DMEM (cat. no.11054001 for the other cell lines) were obtained from Invitrogen Thermo Fisher Scientific, Inc. (Carlsbad, USA), and the medium was supplemented with 10\% FBS (Invitrogen; Thermo Fisher Scientific, California, USA). Cells were cultured in $5 \% \mathrm{CO} 2$ at $37^{\circ} \mathrm{C}$. Incubators used were from Thermo Fisher Scientific, Inc. (Carlsbad, USA).

\section{Reverse transcription-quantitative PCR (RT-qPCR)}

Total RNA was isolated from the frozen tissues and cell lines using TRIzol ${ }^{\circledR}$ reagent (Invitrogen; Thermo Fisher Scientific, Invitrogen, California, USA) and quantified by reading the absorbance at $260 \mathrm{~nm}$. RNA $(2 \mu \mathrm{g})$ was reverse-transcribed using the Revert Aid $^{\mathrm{TM}}$ First Strand cDNA Synthesis kit (Invitrogen; Thermo Fisher Scientific, California, USA.) according to the manufacturer's protocol.

For $\mathrm{qPCR}$, the $\mathrm{SYBR}^{\circledR}$ Premix $\mathrm{Ex}^{\mathrm{Taq}}{ }^{\mathrm{TM}}$ II system (Takara Biotechnology Co., Ltd.) and a Bio-Rad CFX96 ${ }^{\mathrm{TM}}$ Real-time system (Bio-Rad Laboratories, Inc., California, USA) were used. Subsequently, $12.5 \mu \mathrm{ISYBR}^{\circledR}$ Premix Ex Taq $^{\text {TM }}$ II, $1 \mu$ l primer ( $10 \mu \mathrm{M}$, primers; Table 2$), 200 \mathrm{ng}$ cDNA and $9.5 \mu$ l double de-ionized water were mixed. Pre-degeneration was then conducted at $95^{\circ} \mathrm{C}, 30 \mathrm{~s}$, for one repeat, and PCR was performed at $95^{\circ} \mathrm{C}$ for $5 \mathrm{~s}$ followed by incubation at $60^{\circ} \mathrm{C}$ for $30 \mathrm{~s}$, and 35 repeats. Dissociation was then performed at $95^{\circ} \mathrm{C}$ for $15 \mathrm{~s}$ followed by incubation at $60^{\circ} \mathrm{C}$ for $30 \mathrm{~s}$, and a further incubation at

Table 2 Information of the antibodies

\begin{tabular}{|c|c|c|c|c|}
\hline Gene ID & Antibody & Dilutions & Species & Supplied by \\
\hline NM_004360.3 & E-Cadherin & $1: 600$ & homo & Santa Cruz \\
\hline NM_001792.3 & $\mathrm{N}$-Cadherin & $1: 300$ & homo & Santa Cruz \\
\hline NM_003380.3 & Vimentin & $1: 300$ & homo & Santa Cruz \\
\hline NM_005985.3 & Snail1 & $1: 400$ & homo & Santa Cruz \\
\hline NM_001145138.1 & P65 & $1: 300$ & homo & Santa Cruz \\
\hline NM_004530.4 & MMP2 & $1: 400$ & homo & Santa Cruz \\
\hline NM_004994.2 & MMP9 & $1: 400$ & homo & Santa Cruz \\
\hline NM_002046.4 & GAPDH & 1:15000 & homo & Abcam \\
\hline NM_002999.3 & Syndecan-4 & $1: 400$ & homo & Santa Cruz \\
\hline \multirow[t]{3}{*}{ NM_002160.3 } & $\begin{array}{l}\text { Tenascin-C (For } \\
\text { WB) }\end{array}$ & $1: 300$ & homo & Santa Cruz \\
\hline & $\begin{array}{l}\text { Tenascin-C } \\
\text { (peptide) }\end{array}$ & & homo & Millipore \\
\hline & $\begin{array}{l}\text { Tenascin-C } \\
\text { (For functional } \\
\text { blocking) }\end{array}$ & & homo & NOVUS \\
\hline
\end{tabular}


$95^{\circ} \mathrm{C}$ for $15 \mathrm{~s}$ and data collection. GAPDH was used as a loading control.

\section{Western blot analysis}

The cells are harvested when $80 \%$ confluent and washed with cold PBS three times. Total cellular protein lysates were prepared with RIPA buffer [50 mM Tris ( $\mathrm{pH} 8.0)$, $150 \mathrm{mM} \mathrm{NaCl}, 0.1 \%$ SDS, $1 \% \mathrm{NP} 40$ and $0.5 \%$ sodium deoxycholate] containing proteinase inhibitors (1\% cocktail and $1 \mathrm{mM}$ PMSF, Sigma-Aldrich; Merck KGaA, St Louis, MO). Protein $(30 \mu \mathrm{g}$ ) was separated with 6\% (for TN-C) or 10\% (for others) SDS-PAGE and transferred to nitrocellulose membranes. The membranes were blocked at room temperature for $1 \mathrm{~h}$ with $5 \%$ skimmed milk in Tris-buffered saline without Tween-20 (pH7.6, TBS). Polyclonal antibody against TN-C was applied (1:300 dilution; Table 2) with $5 \%$ skimmed milk in TBS at $4{ }^{\circ} \mathrm{C}$ overnight, followed by washing with TBST (with Tween20, pH 7.6). The membranes were then incubated with secondary antibodies (Licor, Rockford, IL, USA) coupled to the primary antibody at room temperature in the dark for $1 \mathrm{~h}$. The membranes were then washed in a dark room, dried with neutral absorbent paper, and scanned using an Odyssey detection system (Licor, Rockford, $I L$, $U S A$ ). Nuclear protein was prepared using a kit (cat. no. BSP001; Sangon Biotech, Shanghai, PRC.) according to the manufacturer's protocol. GAPDH (for total cell fractions) and Histone H1 (for nuclear fractions) were used as loading controls.

\section{Boyden chamber and wound healing assay}

Migration and invasion were examined using a Boyden chamber assay (Millipore, Sigma, Massachusetts, USA). For the migration assay, $0.2 \mathrm{ml}$ FBS-free DMEM suspension with $1 \times 10^{4}$ cells was added to the upper chamber and $0.8 \mathrm{ml}$ FBS-free DMEM was then added to the lower chamber. Following $24 \mathrm{~h}$ of incubation $\left(5 \% \mathrm{CO} 2,37^{\circ} \mathrm{C}\right)$, the chambers were washed with PBS (pH7.4) three times to remove the attached cells in the upper chamber. Prior to staining ( $25 \mathrm{~min}$, room temperature) with crystal violet $(0.01 \%$ in ethanol), the cells were fixed with $4 \%$ formalin for $15 \mathrm{~min}$ (room temperature) and washed three times. The crystal violet-stained cells were under an inverted microscope and five visuals fields were randomly taken acquired under a $\times 200$ objective, and cell counts were averaged. For the invasion assay, suspension in the upper chamber contained $0.2 \mathrm{ml} \mathrm{FBS}$-free DMEM/Matrigel =8/1 (Matrigel; Sigma-Aldrich; Merck KGaA Sigma, St Louis, MO) and $1 \times 10^{4}$ cells were incubated $\left(5 \% \mathrm{CO} 2,37^{\circ} \mathrm{C}\right)$ for $36 \mathrm{~h}$. The cells were treated as described for the migration assay.

Wound healing was assessed by scratching 6-well dishes with a $10-\mu \mathrm{l}$ pipette tip when the cells were $80 \%$ confluent. Scratch widths were compared at 0,12 and $36 \mathrm{~h}$.

\section{Preparation of stable clone cell lines}

PsiCHECK-2 ${ }^{\mathrm{TN}-\mathrm{C}}$ plasmids (plasmid 26,995, http://www. addgene.org) and a vector were transfected into the 5637 and $253 \mathrm{~J}$ (TN-C negative) BCa cell lines, respectively. Lipofectamine $^{\circledR} 2000$ (Invitrogen; Thermo Fisher Scientific, California, USA) was used for transfection according to the manufacturer's instructions and stable cell clones highly expressing TN-C were selected by quantification with Western blot and RT-qPCR analyses.

Short hairpin RNA (shRNA/Sc) to knock down TN-C expression in the T24 and $\mathrm{J} 82$ cells (TN-C positive) was used. pGPU-6-GFP ${ }^{\mathrm{TN}-\mathrm{C} / \mathrm{Sc}}$ was transfected into the cells as mentioned above. Low-TN-C expressing lines were selected using G418 $(600 \mu \mathrm{g} / \mathrm{ml})$, and western blot analysis and RT-qPCR was used to assess the shRNA effects. siRNA to knock down syndecan-4 expression was also used (Table 3). The protocol for transfection using Lipofectamine ${ }^{\circledR} 2000$ was the same as that mentioned above.

\section{BrdU incorporation assay}

BrdU was added to the cell medium $(3 \mu \mathrm{g} / \mathrm{ml})$ after the cells reached $60-70 \%$ confluency on coverslips, followed by incubation (room temperature) for $4 \mathrm{~h}$. The coverslips were then rinsed three times with PBS for $10 \mathrm{~min}$ to remove free $\mathrm{BrdU}$ and the samples were fixed in $4 \%$ paraformaldehyde for $45 \mathrm{~min}$, followed by rinsing five times with PBS for $20 \mathrm{~min}$. Subsequently, 0.1\% Triton X-100 was added to destroy the cell membrane $(15 \mathrm{~min})$ and $2 \mathrm{M} \mathrm{HCl}(25 \mathrm{~min})$ were added to separate DNA into single strands for primary antibody access to incorporated BrdU. Before blocking non-specific epitopes with $10 \%$ BSA for $20 \mathrm{~min}$, the cells were rinsed three times with PBS for $10 \mathrm{~min}$ to remove $\mathrm{HCl}$ and Triton. Subsequently, $10 \%$ BSA with anti-BrdU antibody (1:200, cat 8152 Waltham, MA USA) was added followed by incubation overnight at $4^{\circ} \mathrm{C}$. The following day, the cells were rinsed five times with PBS to remove free antibody, and were incubated with TRITC-labeled secondary antibody for $1 \mathrm{~h}$ at room temperature and rinsed a further three times with PBS to remove free antibody. The fluorescence intensity of TRITC was monitored using a Super Micro Orifice Plate Spectrophotometer (BioTek Instruments, Vermont, $U S A$ ) at $547 \mathrm{~nm}$.

\section{ELISA}

$\mathrm{TN}-\mathrm{C}$ in the cell medium was measured by ELISA. Briefly, cell (different groups) media were collected and examined by ELISA according to the kit instructions (Human TN-C ELISA kit, Shanghai Westang Biological 
Table 3 Primers for Real-time PCR and siRNA/shRNA

\begin{tabular}{|c|c|c|c|}
\hline Gene ID & Gene & Primers & \\
\hline \multirow[t]{2}{*}{ NM_001145138.1 } & P65 & $\mathrm{F}$ & ACG AAT GAC AGA GGC GTG TAT AAG G \\
\hline & & $\mathrm{R}$ & CAG AGC TGC TTG GCG GATTAG \\
\hline \multirow[t]{2}{*}{ NM_002046.4 } & GAPDH & $\mathrm{F}$ & AAC AGC GAC ACC CAT CCT C \\
\hline & & $\mathrm{R}$ & CAT ACC AGG AAA TGA GCT TGA CAA \\
\hline \multirow[t]{2}{*}{ NM_004360.3 } & E-Cadherin & $\mathrm{F}$ & TGC CCA GAA AAT GAA AAA GG \\
\hline & & $\mathrm{R}$ & GTG TAT GTG GCA ATG CGTTC \\
\hline \multirow[t]{2}{*}{ NM_001792.3 } & $\mathrm{N}$-Cadherin & $\mathrm{F}$ & ACA GTG GCC ACC TAC AAA GG \\
\hline & & $\mathrm{R}$ & CCG AGA TGG GGT TGA TAA TG \\
\hline \multirow[t]{2}{*}{ NM_003380.3 } & Vimentin & $\mathrm{F}$ & GAG AAC TTT GCC GTT GAA GC \\
\hline & & $\mathrm{R}$ & GCTTCC TGT AGG TGG CAA TC \\
\hline \multirow[t]{2}{*}{ NM_005985.3 } & Snail1 & $\mathrm{F}$ & ACC CCA ATC GGA AGC CTA ACT \\
\hline & & $\mathrm{R}$ & GGT CGT AGG GCT GCT GGA A \\
\hline \multirow[t]{2}{*}{ NM_004530.4 } & MMP2 & $\mathrm{F}$ & CTC ATC GCA GAT GCC TGG AA \\
\hline & & $\mathrm{R}$ & TTC AGG TAA TAG GCA CCC TTG AAG A \\
\hline \multirow[t]{2}{*}{ NM_004994.2 } & MMP9 & $\mathrm{F}$ & TGA CAG CGA CAA GAA GTG \\
\hline & & $\mathrm{R}$ & CAG TGA AGC GGT ACA TAG G \\
\hline \multirow[t]{4}{*}{ NM_002999.3 } & Syndecan-4 & $\mathrm{F}$ & CCA GTT TGA TGT TGC TGG GTG GTT \\
\hline & & $\mathrm{R}$ & AGC CCT AGA GCC TGA AGA AAG CAA \\
\hline & Syndecan-4 siRNA & $\mathrm{Si}$ & 5 -AAG GCC GAT ACT TCT CCG GAG-3 \\
\hline & & Sc & 5 -AAG GCT CTC CGG AGC GATA CT-3 \\
\hline \multirow[t]{4}{*}{ NM_002160.3 } & Tenascin-C & $\mathrm{F}$ & AGC TTC CAA GAA ACA CCA CTT C \\
\hline & & $\mathrm{R}$ & CCA TCC CAG CCA ACC TCA \\
\hline & Tenascin-C shRNA & $\mathrm{F}$ & $\begin{array}{l}\text { 5'-CAC CGC ACC TGA AGG CCT GAA } \\
\text { ATT CTT CAA GAG AGA ATT TCA GGC } \\
\text { CTT CAG GTG CTTTTTTG-3' }\end{array}$ \\
\hline & & $\mathrm{R}$ & $\begin{array}{l}\text { 5'-GAT CCA AAA AAG CAC CTG AAG } \\
\text { GCC TGA AAT TCT CTC TTG AAG AAT } \\
\text { TTC AGG CCT TCA GGT GC-3' }\end{array}$ \\
\hline
\end{tabular}

Technology Co., Ltd. Shanghai, PRC), and optical density was measured at $450 \mathrm{~nm}$. Data are expressed in $\mu \mathrm{g} / \mathrm{ml}$.

\section{Immunofluorescence staining for the nuclear translocation of NF-KB}

The prepared cells were washed three times in cold PBS (pH7.4) and fixed with 4\% paraformaldehyde for $15 \mathrm{~min}$, followed by permeabilization in $0.5 \%$ Triton X-100 for $10 \mathrm{~min}$ and blocking with $1 \%$ BSA for $1 \mathrm{~h}$. Rabbit antihuman p65 in 1\% BSA was added to the medium and incubated overnight at $4{ }^{\circ} \mathrm{C}$. Mouse anti-rabbit TRITC (red) IgG antibody (Santa Cruz Biotechnology, Texas, USA) diluted 1:100 in blocking buffer was added to the medium and incubated (room temperature) for $1 \mathrm{~h}$. The cells were then washed with cold PBS three times and cell nuclei were stained with DAPI $(10 \mu \mathrm{g} / \mathrm{ml}$, Sigma-Aldrich; Merck KGaA Sigma, St Louis, USA) for 3 min. Cells were observed under an Image Pro Plus System mounted on a fluorescence microscope (Olympus Corporation, Tokyo, Japan).

\section{Other reagent and experiments}

TN-C peptide (Millipore Sigma, Massachusetts, USA) was an exogenous $\mathrm{TN}-\mathrm{C}$ added to the media $(1 \mu \mathrm{g} / \mathrm{ml})$, and TN-C-neutralizing antibody $(1 \mu \mathrm{g} / \mathrm{ml})$ (3358-TC, Novus Biologicals, Briarwood Avenue, USA;) was used to neutralize TN-C in the media.

Statistical analysis Statistical analysis was performed using the SPSS 19.0 statistic package (SPSS, Inc., Chicago, USA.). For comparisons among different groups, oneway ANOVA was used, and for comparisons between two different groups, the student's t-test was used. A Shapiro-Wilk test was used to confirm the distribution of survival time of the $\mathrm{BCa}$ patients. $P<0.05$ was considered to indicate statistically significant differences.

\section{Results}

$\mathrm{TN}-\mathrm{C}$ expression in $\mathrm{BCa}$ tissue increases with tumor grade and is an independent risk factor for $\mathrm{BCa}$

To examine the expression of TN-C in $\mathrm{BCa}$ tissues in local Chinese patients and its significance in clinical 
practice, TN-C expression was measured in BCa tissues obtained from Chinese patients. As shown in Fig. 1A and $\mathrm{B}, \mathrm{TN}-\mathrm{C}$ expression across different grades of $\mathrm{BCa}$ tissues differed and increased with the tumor grade. In addition, it was observed that the $\mathrm{BCa}$ tumor grade was an independent risk factor for $\mathrm{BCa}$ patients (Fig. 1C). To examine TN-C expression and patient survival, the patients were stratified into the high or low TN-C expression groups. As shown in Fig. 1D, TN-C expression exceeded the mean, suggesting a poor survival, and these data are in agreement with previous findings [46]. Finally, an association analysis suggested that TN-C expression in $\mathrm{BCa}$ tissue was negatively associated with tumor-free survival (Fig. 1E).

\section{Preparation of stable high and low TN-C-expressing cell lines}

As it was suggested that $\mathrm{TN}-\mathrm{C}$ expression may drive $\mathrm{BCa}$ progression, $\mathrm{TN}-\mathrm{C}$ expression was measured in $\mathrm{BCa}$ cell lines of different tumor grades. It is known that TN-C is secreted into the ECM. Thus, the present study measured TN-C expression in cell media to monitor this secretion. The data indicated the diverse expression of $\mathrm{TN}-\mathrm{C}$ in $\mathrm{BCa}$ cell lines (Fig. 2A and B). The T24 and J82 cells exhibited a higher TN-C expression, while the 5637 and 253 J cells exhibited a lower TN-C expression. The results of ELISA were in agreement with those of western blot analysis and RT-qPCR, suggesting that TN-C may function as a secreted protein (Fig. 2C).

To elucidate the mechanisms through which TN-C contributes to $\mathrm{BCa}$ progression, $\mathrm{TN}-\mathrm{C}$ expression was
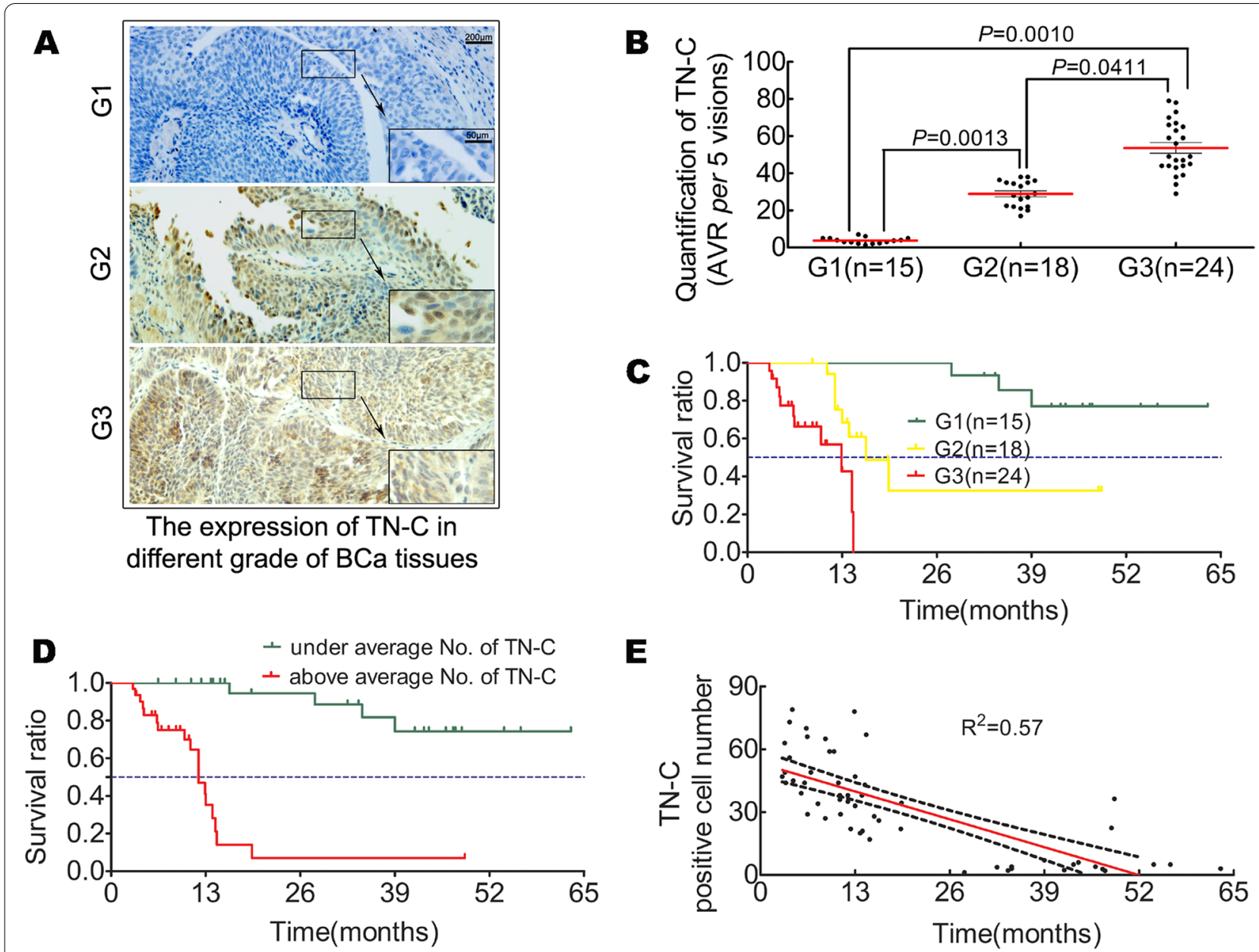

$\mathbf{E}$

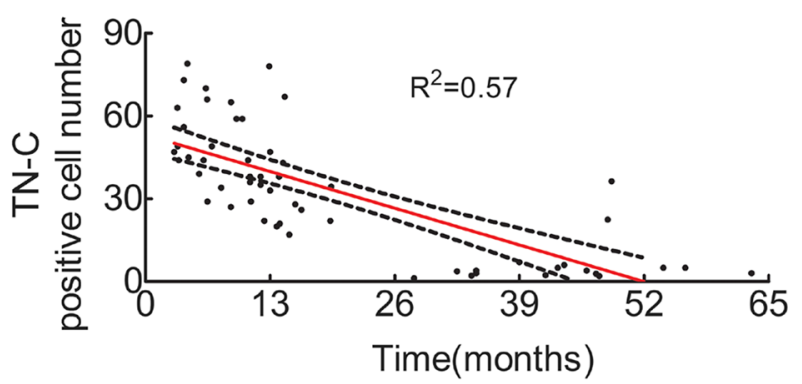

Fig. 1 TN-C expression in BCa tissue and clinical significance. A Representative figures of IHC staining for TN-C in different BCa tissues; $\mathbf{B}$ Quantification of IHC staining for TN-C in different BCa tissues, indicating elevated expression of TN-C according to $B C$ a tumor grade, $P<0.05 ; C$ Kaplan-Meier analysis suggests that tumor grade is an independent risk factor for BCa; $\mathbf{D}$ Kaplan-Meier analysis indicates that TN-C expression in $\mathrm{BCa}$ tissue is an independent risk factor for $\mathrm{BCa}$, based on normal survival distribution demonstrated by the Shapiro-Wilk test. Patients are stratified by average TN-C positive cells: green line indicates under average; red line indicates above average, $P<0.05$; E Correlation analysis suggests that tumor-free survival is negatively associated with TN-C expression in BCa patients, $P<0.05$ 


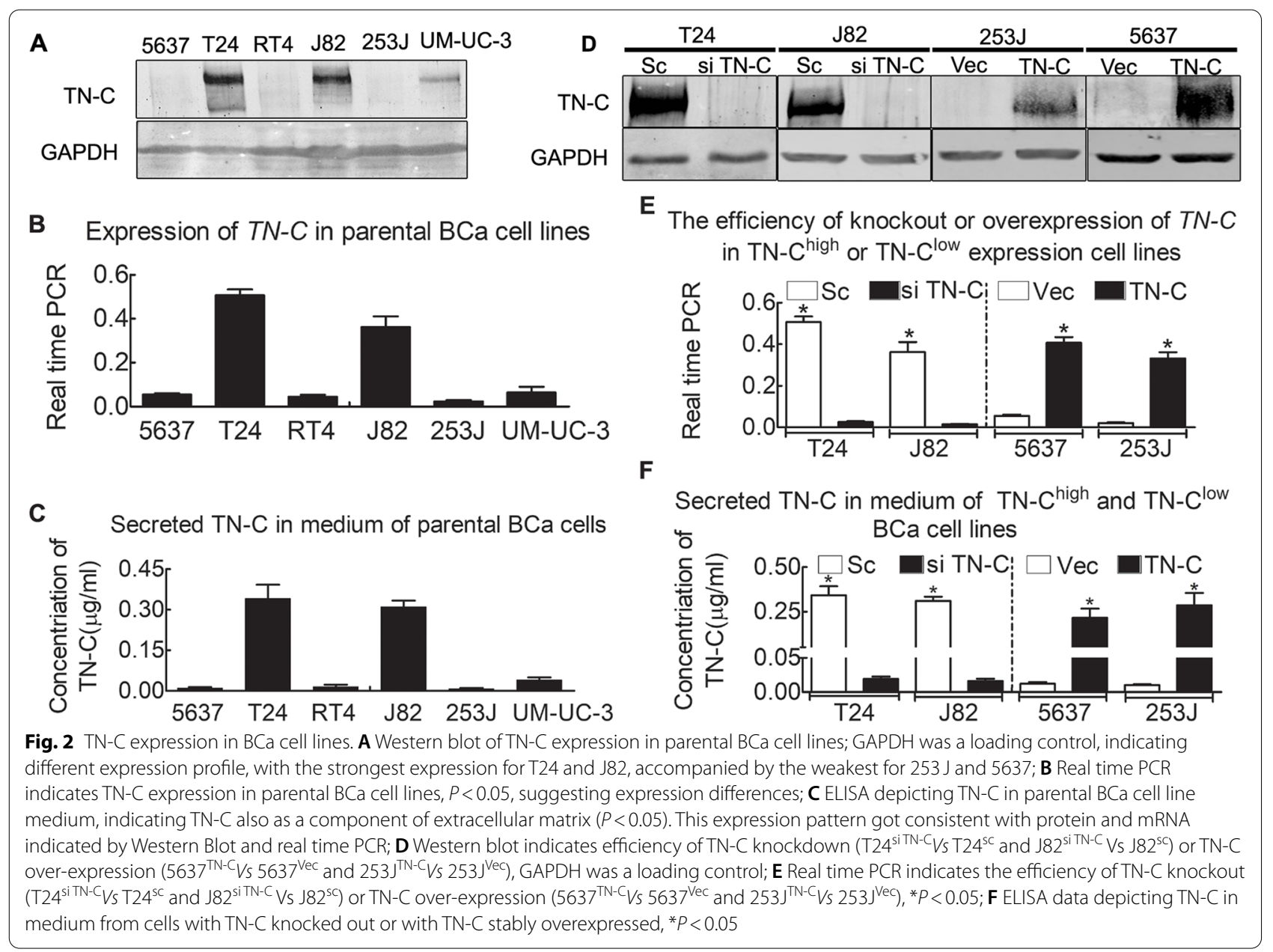

silenced in BCa cell lines, and malignancy and proliferation were monitored. Briefly, the T24 and J82 cells, TN$\mathrm{C}$-positive cell lines, were used and TN-C was knocked down with shRNA/Sc. The 5637 and $253 \mathrm{~J}$ cells, TN$\mathrm{C}$-negative cell lines, were then manipulated to overexpress TN-C with a plasmid as described in Materials and methods. The TN-C-knockdown or overexpression (Fig. 2D-F) indicated successful transfection efficiencies.

\section{TN-C enhances the migration, invasion and proliferation of BCa cell lines}

$\mathrm{TN}-\mathrm{C}$ contributes to tumor migration, invasion and proliferation in diverse tumors, including breast cancer, melanoma and pancreatic cancer. The data of the present study demonstrated that TN-C was vital for $\mathrm{BCa}$ progression. TN-C was knocked down in the T24 and J82 cell lines, and a reduced cancer cell migration and invasion (Fig. 3A, upper panels), an attenuated proliferation (Fig. 3B, upper panels), and a delayed and prolonged wound healing (Fig. 3C, upper panels) were noted. TN-C overexpression in 5637 and 253 J cells enhanced migration and invasion (Fig. 3A, bottom panels), increased proliferation (Fig. 3B, bottom panels) and accelerated wound healing (Fig. 3C, bottom panels).

Research suggests a complex role for TN-C as an ECM component [15]; however, in the present study, the TN-C staining data from $\mathrm{BCa}$ tissues indicated that the ECM deposition of TN-C occurred beyond the cytoplasm. Thus, tumor cells exposed to exogenous TN-C may be modified. Human TN-C peptide (which was used as exogenous $\mathrm{TN}-\mathrm{C}$ ) was added to the media of TN-C-negative cell lines ( $\mathrm{T} 24^{\mathrm{siTN}-\mathrm{C}}, \mathrm{J} 82^{\text {siTN-C }}, 5637^{\mathrm{Vec}}$ and $\left.253 \mathrm{~J}^{\mathrm{Vec}}\right)$, and human TN-C-neutralizing antibody was added to TN-C-positive cell lines $\left(\mathrm{T} 24^{\mathrm{Sc}}, \mathrm{J} 82^{\mathrm{Sc}}, 5637^{\mathrm{TN}-\mathrm{C}}\right.$ and $253 \mathrm{~J}^{\mathrm{TN}-\mathrm{C}}$ ). Boyden chamber, wound healing and BrdU incorporation assays were then performed to assessed malignancy.

Exogenous TN-C (Ex TN-C, Ex) enhanced the migration, invasion and proliferation of $5637^{\mathrm{Vec}}$ cells (Fig. 4 A-C: $5637^{\mathrm{Vec}}$, Con vs. Ex), while the knockdown of TN-C attenuated T24 cell migration, invasion and proliferation. This effect was attenuated by exogenous TN-C 

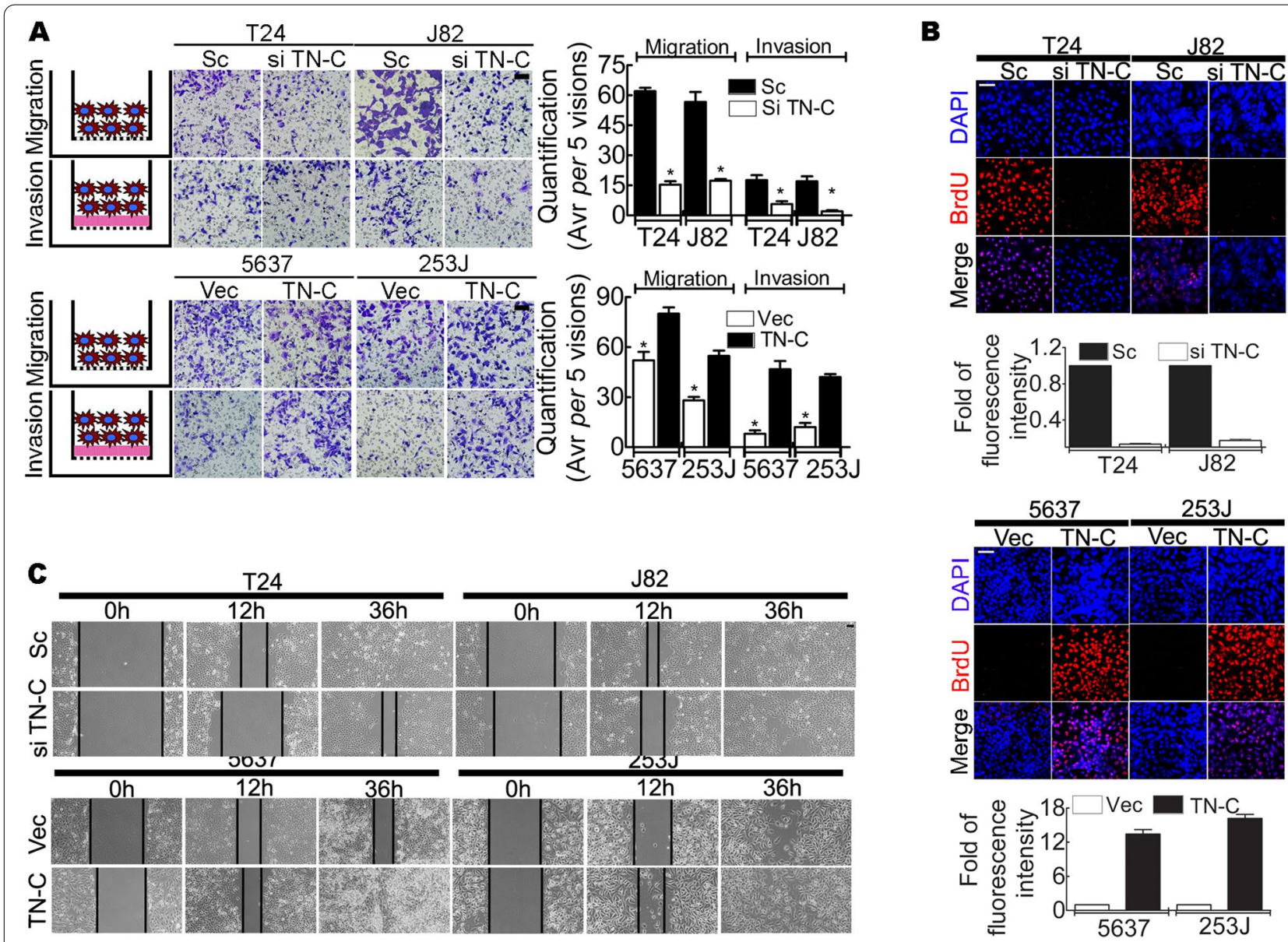

Fig. 3 TN-C contributes to BCa cell line proliferation, migration, and invasion. A Boyden chamber assay, indicating that TN-C contributes to tumor cell migration and invasion. Left: cartoon of tumor cell with or without Matrigel (pink area), middle: representative figures, Bar: $100 \mu$ m; right: quantification, ${ }^{*} P<0.05$; B BrdU incorporation, indicating that TN-C contributes to tumor cell proliferation. Upper: representative figures, bar: $100 \mu \mathrm{m}$; lower: relative fluorescent intensity; $\mathbf{C}$ Wound healing analysis at 0,12 , and $36 \mathrm{~h}$ suggesting that TN-C leads reduces wound healing time, Bar: $100 \mu \mathrm{m}$

(Fig. 4A-C: T24 siTN-C, Con vs. Ex). TN-C-neutralizing antibody added to the media decreased the migration, invasion and proliferation of $\mathrm{T} 24^{\mathrm{Sc}}$ (Fig. 4A-C: T24 ${ }^{\mathrm{Sc}}$, Con vs. Anti) and $5637^{\mathrm{TN}-\mathrm{C}}$ (Fig. 4A-C: $5637^{\mathrm{TN}-\mathrm{C}}$, Con vs. Anti) cells.

TN-C contributes to the elevated expression of EMT-related markers and the expression of MMP2/MMP9 by activating NF-KB signaling

The data demonstrated that $\mathrm{TN}-\mathrm{C}$ promoted $\mathrm{BCa}$ cell migration, invasion and proliferation; however, the underlying mechanisms were not clear. TN-C may perform this function as a component of the ECM, at least partially. In transitional cell carcinoma, the enhanced migration and invasion of tumor cells is often accompanied by EMT [47], and this can be used to monitor the malignant behavior of $\mathrm{BCa}$ cells. The activation of NF-kB has been causally linked to an invasive phenotype, and can directly or indirectly induce the expression of Snail, Slug, Twist, Zeb1 and Zeb2 [48], all of which are markers of EMT. Thus, it was hypothesized that the TN-Cinduced effects may involve NF- $\mathrm{B}$ signaling. The data from western blot analysis and RT-qPCR to monitor the expression of EMT-related markers, and immunofluorescence staining to quantify NF- $\mathrm{kB}$ signaling confirmed the data from the Boyden chamber and wound healing assays. In addition, the knockdown of TN-C in T24 cells confirmed the decreased expression of MMP2/MMP9, vimentin, $\mathrm{N}$-cadherin and Snail, and this was accompanied by the elevated expression of E-cadherin (Fig. 5A and $\mathrm{B}, \mathrm{T} 24^{\mathrm{Sc}}-\mathrm{Con}$ vs. $\mathrm{T} 24^{\mathrm{siTN}-\mathrm{C}_{-}}$Con), indicating the reversal of EMT.

Moreover, this process was reversed in 5637 cells overexpressing $\mathrm{TN}-\mathrm{C}$, which caused the elevated expression of MMP2/MMP9, vimentin, N-cadherin and Snail, and the decreased expression of E-cadherin (Fig. 5A 

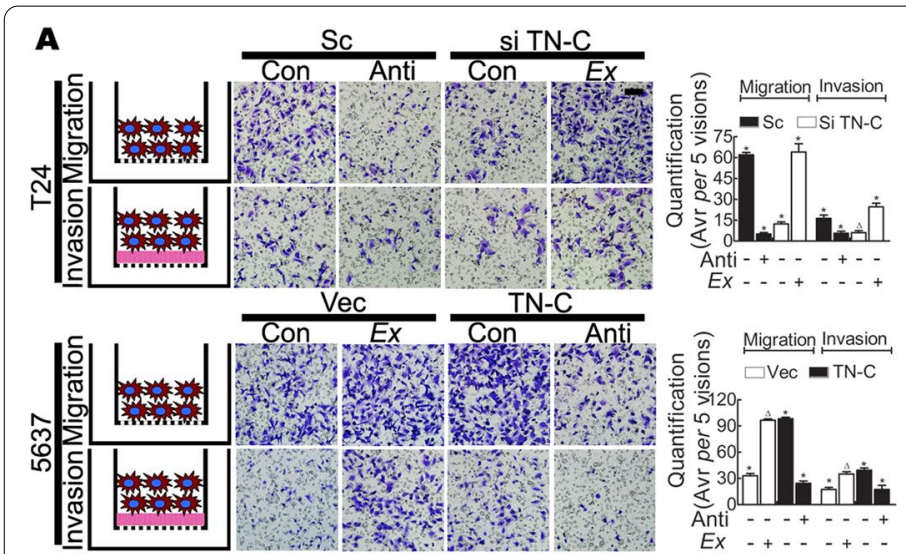

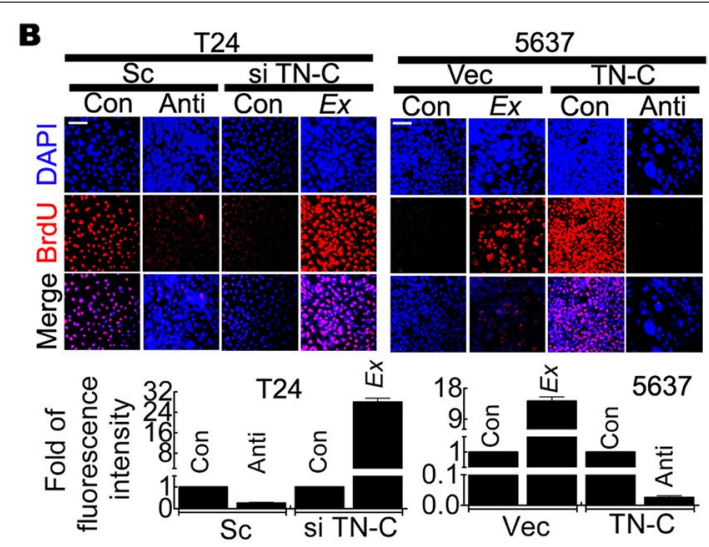

C

Oh $12 \mathrm{~h}$
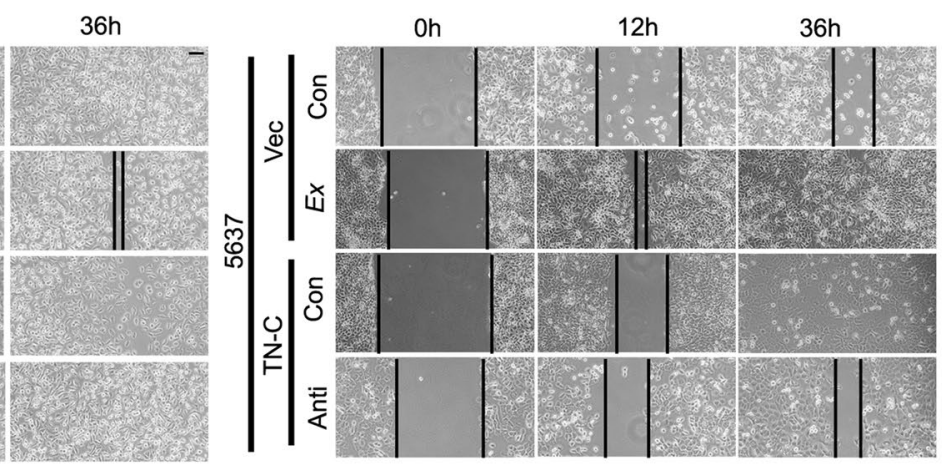

Anti: TN-C Neutralizing antibody $\square ;$ Ex: Exogenous TN-C(Human Tenascin-C Purified Protein )

Fig. 4 TN-C promotes tumor invasion, migration and proliferation as a secreted glycoprotein. A Boyden chamber assay indicates that TN-C promotes BCa cell migration and invasion as secreted glycoprotein. Left: cartoon of tumor cell with or without Matrigel (pink area); Middle: representative figures, Bar: $100 \mu \mathrm{m}$; Right: quantification, $P<0.05$. The exogenous TN-C (Ex) promotes tumor cell migration and invasion (T24

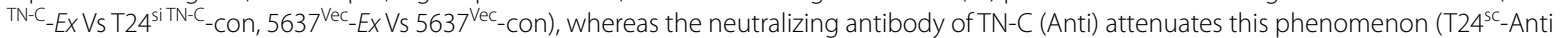

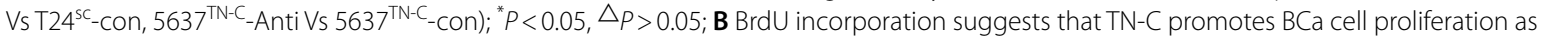
secreted glycoprotein. Upper: representative figures, Bar: $100 \mu \mathrm{m}$; Lower: relative fluorescent intensity. The exogenous TN-C (Ex) leads to tumor

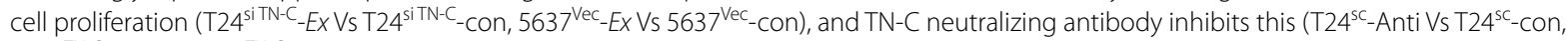
$5637^{\mathrm{TN}-\mathrm{C}}$-Anti Vs $5637^{\mathrm{TN}-\mathrm{C}}$-Con); C Wound healing analysis indicates that TN-C promotes BCa cell wound healing also as secreted glycoprotein.

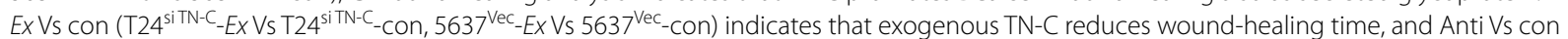
(T24 $4^{\text {SC }}$-Anti Vs T24 $4^{\text {SC }}$-Con, 5637 ${ }^{\text {TN-C}}$-Anti Vs $5637^{\text {TN-C }}$-Con) indicates that neutralizing antibody prolongs this duration. Bar: $100 \mu \mathrm{m}$

and $\mathrm{B}, 5637^{\mathrm{Vec}}-$ Con vs. $5637^{\mathrm{TN}-\mathrm{C}}-$ Con). The effect of knocking down TN-C in T24 cells was reversed with Ex TN-C (Fig. 5A and B, T24 ${ }^{\text {siTN-C }-C o n ~ v s . ~ T 24 ~} 4^{\text {siTN-C }}-$ Ex), and TN-C-neutralizing antibody significantly inhibited the expression of these genes in T24 $4^{\mathrm{Sc}}$ cells (Fig. $5 \mathrm{~A}$ and $\mathrm{B}, \mathrm{T} 24^{\mathrm{Sc}}$-Con vs. T24 $4^{\mathrm{Sc}}$-Anti). Similar data were obtained with the 5637 cells; Ex TN-C (Fig. 5A and B, $5637^{\mathrm{Vec}}$-Con vs. $5637^{\mathrm{Vec}}$-Ex) promoted EMT, and TN-Cneutralizing antibody inhibited this effect (Fig. 5A and B, $5637^{\mathrm{TN}-\mathrm{C}}$-Con vs. $5637^{\mathrm{TN}-\mathrm{C}}$-Anti).

In addition, TN-C induced the activation of NF- $\mathrm{KB}$ signaling [34]. p65 is the functional subunit of the NF-kB dimer (p65/p50), and the nuclear translocation of this subunit is considered to activate this signaling. As shown in Fig. $5 \mathrm{C}, \mathrm{TN}-\mathrm{C}$ induced the nuclear translocation of p65 in $\mathrm{T} 24^{\mathrm{siTN}-\mathrm{C}}$ vs. $\mathrm{T} 24^{\mathrm{Sc}}$ cells and in $5637^{\mathrm{Vec}}$ vs. $5637^{\mathrm{TN}-\mathrm{C}}$ cells, as well as in the T24 ${ }^{\text {siTN-C }}$-Con vs. T2 $4^{\text {siTN- }}$ C-Ex and $5637^{\text {Vec }}$-Con vs. $5637^{\mathrm{Vec}}$-Ex. However, the nuclear translocation of p65 was suppressed by the functional inhibition of TN-C (Fig. 5C, T2 $4^{\mathrm{Sc}}$-Con vs. T24 $4^{\mathrm{Sc}}$-Anti and $5637^{\mathrm{TN}-\mathrm{C}}$-Con vs. $5637^{\mathrm{TN}-\mathrm{C}}$-Anti).

\section{$\mathrm{TN}-\mathrm{C}$ induced activation of NF-KB signaling is dependent on syndecan-4}

TN-C chiefly functions as a component of the ECM, indicating an interaction between $\mathrm{TN}-\mathrm{C}$ and tumor cells [49]. Syndecan-4 has also been reported to be the receptor involved in these interactions. Briefly, syndecan- 4 is considered as a co-receptor of syndecan- $4 / \alpha 5 \beta 1$, which is crucial for cell adhesion. Interference with this 

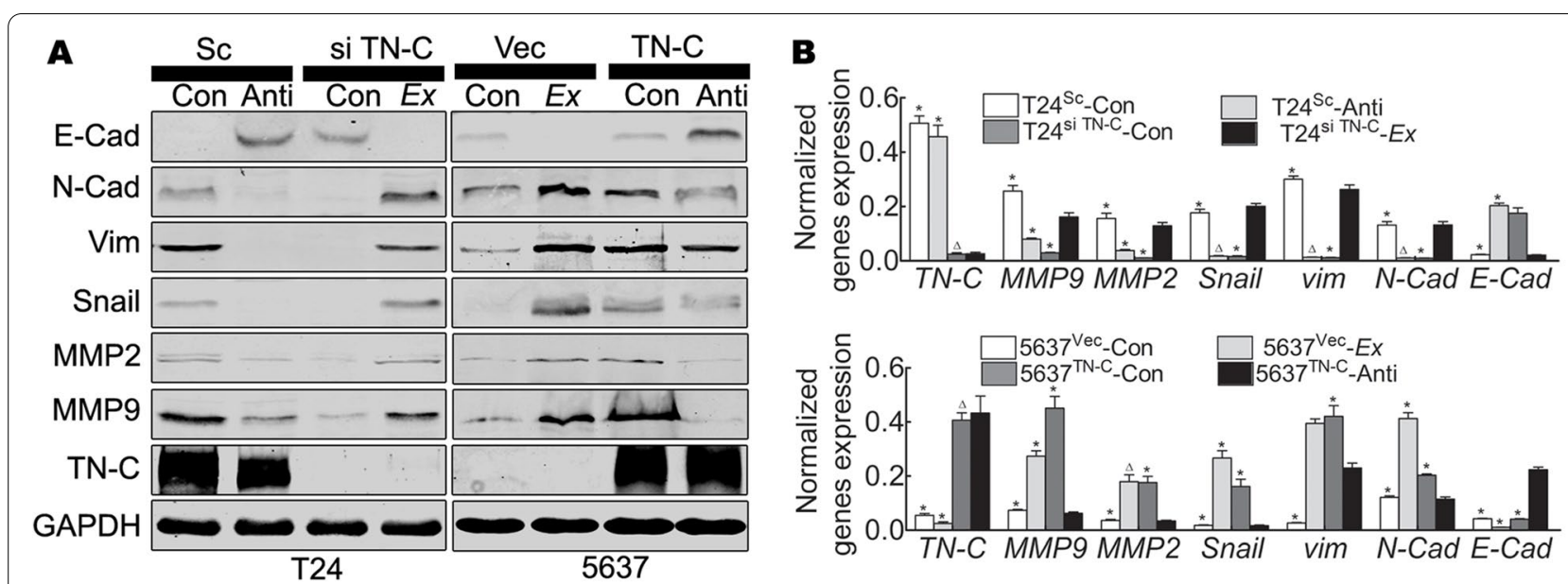

C

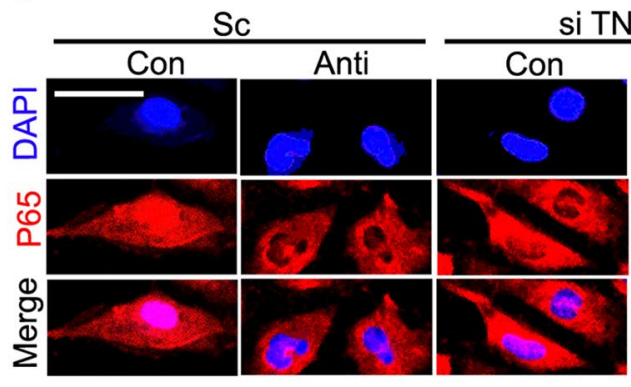

T24

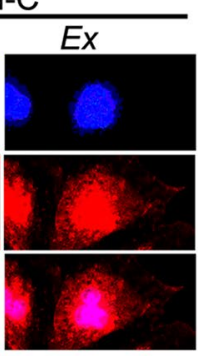

, leading to EMT. A Western blot indicates that secreted TN-C induces upregulation of $\mathrm{N}-\mathrm{Cad}$, Vim, Snail, MMP 2 and $\mathrm{MMP}_{9}$ and downregulation of E-Cad; GAPDH was a loading control; $\mathbf{B}$ Real time PCR agrees with Western blot, ${ }^{*} P<0.05$, $\triangle P>0.05 ; C$ Immunofluorescent staining suggests that secreted TN-C contributes to nuclear translocation of NF-kB (P65), activating signaling, Bar: $20 \mu \mathrm{m}$ co-receptor causes tumor cell proliferation and metastases; thus, the functions of TN-C may be dependent on this membrane receptor in the $\mathrm{BCa}$ cell line. To assess this, the present study measured the expression of syndecan- 4 in all BCa cell lines. The results revealed that a significant syndecan-4 expression was observed in all lines (Fig. 6A). No apparent differences were observed among cell lines. The T24 and 5637 cells were selected to represent TN-C-positive and negative-cell lines, respectively, and the role of syndecan- 4 was examined by knocking down its expression with siRNA.

Two TN-C related stable cell clones, T2 $4^{\mathrm{Sc} / \mathrm{siTN}-\mathrm{C}}$ and $5637^{\mathrm{Vec} / \mathrm{TN}-\mathrm{C}}$ cells, were also subjected to syndecan-4 knockdown and the effects of TN-C on that expression were examined. The data indicated that syndecan-4 expression was knocked down in both cell lines; however, the knockdown of TN-C did not affect syndecan-4 expression (Fig. 6B).

To determine whether syndecan-4 knockdown in both cell lines can modify migration and invasion, a Boyden chamber assay was performed and syndecan-4 knockdown was noted to decrease the migration and invasion of both cell lines. The effects of the overexpression of TN-C (in 5637 cells) or the exogenous addition of TN-C (in T24 $4^{\text {siTN-C }}$ and $5637^{\mathrm{Vec}}$ cells) were attenuated (Fig. 6C).

In addition, syndecan-4 interference inhibited p65 nuclear translocation, blocking signal activation, as shown by immunofluorescence staining (Fig. 6D). The effects of the overexpression of TN-C (in 5637 cells) or the addition of Ex TN-C (in T24 $4^{\text {siTN-C }}$ and $5637^{\mathrm{Vec}}$ cells) were also blocked by syndecan-4 knockdown. Thus, $\mathrm{TN}-\mathrm{C}$ promotes cancer cell line migration, invasion and proliferation, as well as the activation of NF- $\mathrm{kB}$ signaling, and these effects are dependent on syndecan- 4 .

\section{Discussion}

The high recurrence rate of $\mathrm{BCa}$ is likely attributed to the interactions of tumor cells with the surrounding microenvironment to drive progression, metastasis and drug resistance. Macrophages from prostate cancer tissue can induce cancer phenotypes of normal prostate epithelial cells when co-cultured [50]. In addition, fibroblasts, inflammatory cells and the ECM play vital roles in cancer, among which, TN-C is the least extensively investigated. 


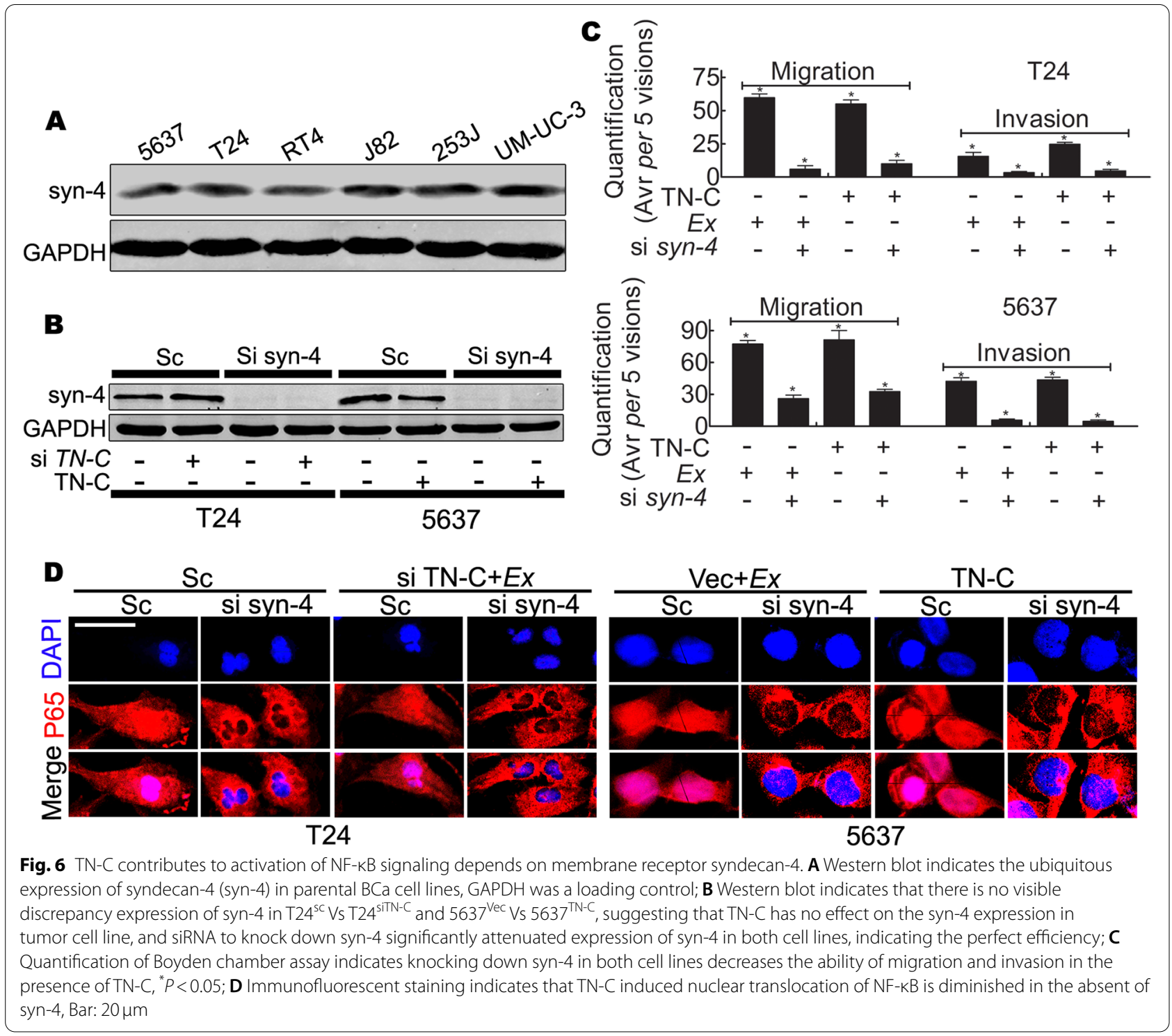

TN-C has been reported to be crucial for embryogenesis, inflammation and wound healing, and functions in a similar manner in tumorigenesis. TN-C expression in cancerous tissues has been documented in various tumors and is considered to be an independent risk factor for patients with cancer. Consistent with the literature [51], TN-C expression data for $\mathrm{BCa}$ tissue in the present study suggested that it plays a positive role in $\mathrm{BCa}$ progression; however, TN-C expression across different $\mathrm{BCa}$ cell lines is diverse and is not associated with tumor grade. For example, in 5637 cells, $\mathrm{TN}-\mathrm{C}$ expression is not observed in grade II $\mathrm{BCa}$, and this may be explained by the different sources of TN-C. In BCa cell lines, cancer is the sole $\mathrm{TN}-\mathrm{C}$ source, although tumor cell secretions or mesenchymal cells can also produce TN-C.
Previous studies have suggested a vital role of TN-C in tumor progression and the $\mathrm{TN}-\mathrm{C}$ content in $\mathrm{BCa}$ cell lines is consistent with tumor cell $\mathrm{TN}-\mathrm{C}$ expression (Fig. 2A and C). Modifying TN-C expression in BCa cell lines causes the same effect to the TN-C concentration in the corresponding BCa cell lines (Fig. 2D and F). Thus, secreted TN-C may be a primary source of TN-C tumor activity. TN-C-neutralizing antibody reduces $\mathrm{TN}-\mathrm{C}$ overexpression, as does human TN-C peptide (Fig. 4). Thus, in BCa cell lines, TN-C executes its role mainly as a component of the ECM, perhaps by binding with membrane receptors. Investigations have confirmed that the coreceptor of syndecan-4/ $\alpha 5 \beta 1$ is important for tumor cell adhesion to fibronectin of the ECM [28], and that interference with this function by TN-C decreases tumor cell 
adhesion and enhances metastasis and proliferation. Syndecan-4 is the sole syndecan family member that is ubiquitously expressed in the cell membrane. A number of downstream signals of syndecan-4 are known, including PKC $\alpha$, PKC $\delta$, PI3K/Akt and synectin [29, 52]. Previous studies have suggested that interference with the syndecan- $4 / \alpha 5 \beta 1$ co-receptor in the cell membrane inhibits normal cell proliferation and enhances tumor cell proliferation; however, the mechanisms responsible for this remain unclear [26, 27].

The present study found that the knockdown of syndecan-4 expression attenuated TN-C-induced tumor migration, invasion and proliferation, suggesting that $\mathrm{TN}-\mathrm{C}$ contributes to metastasis and proliferation in a manner that is dependent on syndecan-4. However, the mechanisms through which $\mathrm{TN}-\mathrm{C}$ binds to membrane syndecan- 4 and those underlying its association with metastasis and proliferation are not yet known. The enforced expression of TN-C or in the presence of Ex TN-C increased the levels of mesenchymal markers (elevated expression of vimentin, Snail, N-cadherin and MMP2/MMP9) and decreased the expression of E-cadherin (Fig. 5A and B) in the BCa cell lines, indicating that the alternative expression of these genes may be related to the activation of NF- $\mathrm{kB}$ signaling.
The present study provides evidence that in $\mathrm{BCa}$ cell lines, the activation of NF- $\mathrm{kB}$ signaling leads to EMT, manifested as previously depicted [53]. Immunofluorescence staining confirmed that the binding of $\mathrm{TN}-\mathrm{C}$, either by the enforced expression or exogenous $\mathrm{TN}-\mathrm{C}$, with syndecan-4 induced the nuclear translocation of p65, a process that was inhibited by syndecan- 4 knockdown (Fig. 6D). Thus, the binding of TN-C with syndecan-4 induces the activation of NF- $\mathrm{KB}$ signaling, and promotes tumor cell metastasis and proliferation.

A summary of the present study is illustrated in Fig. 7. NF- $\mathrm{KB}$ is downstream of the PI3K/Akt pathways, suggesting that $\mathrm{TN}-\mathrm{C}$ binding with syndecan- 4 may induce the activation of NF-kB signaling is involved in PI3K/Akt pathway activation via the cytoplasmic domain of syndecan-4. Whether the binding of TN-C with syndecan-4 involves the co-receptor $\alpha 5 \beta 1$ remains unknown.

\section{Conclusion}

In summary of the present study, our data suggested that $\mathrm{TN}-\mathrm{C}$ promotes tumor cell metastasis and proliferation, and that this is dependent on syndecan-4 mediated activation of NF- $\mathrm{kB}$ signal activation, although the mechanism of which was still unknown. These data offer a solid foundation for future studies on the role of

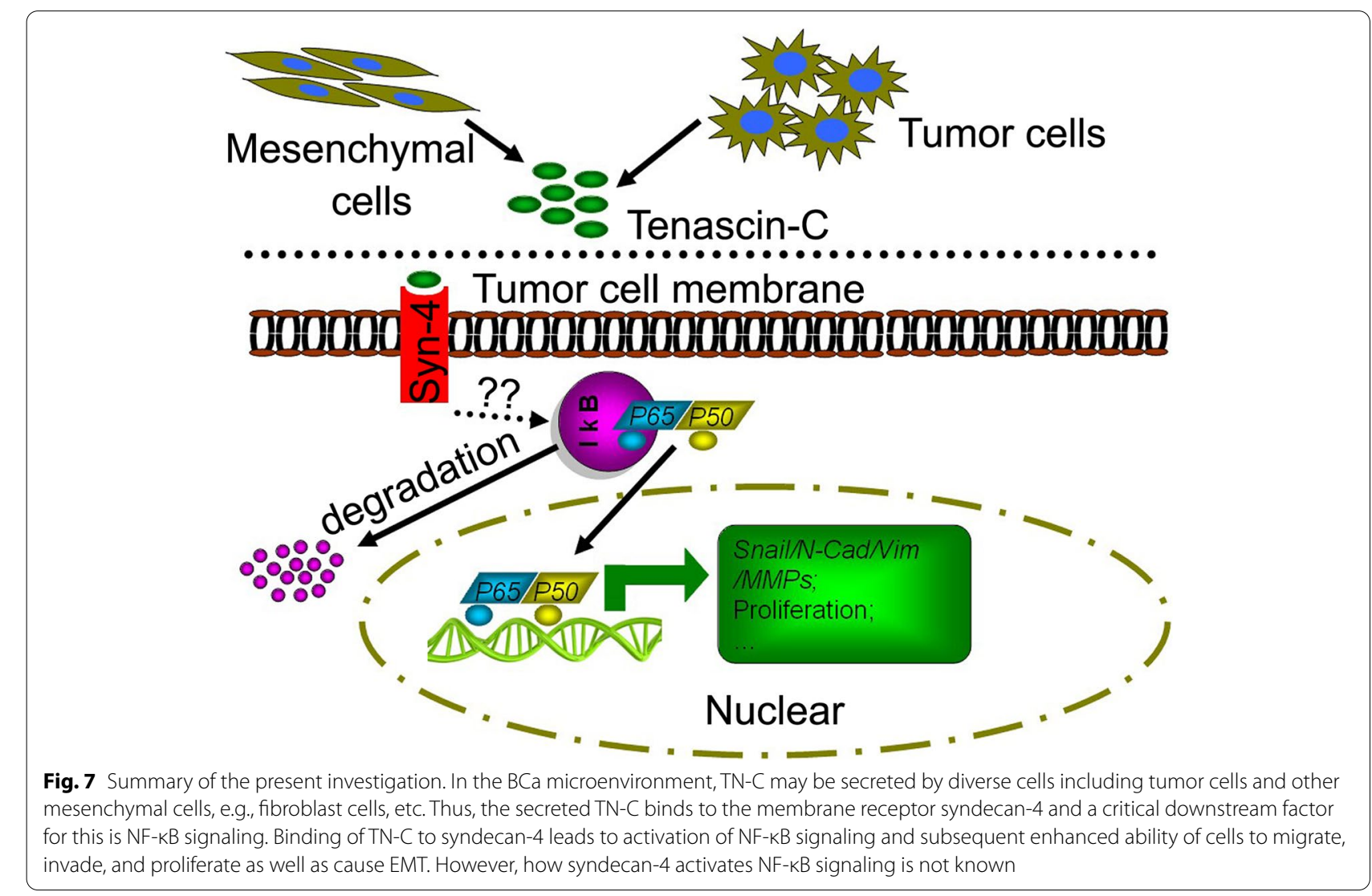


$\mathrm{TN}-\mathrm{C}$ in $\mathrm{BCa}$ progression and suggest that $\mathrm{TN}-\mathrm{C}$ may be a potential therapeutic target in the treatment of $\mathrm{BCa}$.

\begin{abstract}
Abbreviations
BCa: Bladder Cancer; CIS: Carcinoma in situ; EMT: Epithelial-mesenchymal transition; ECM: Extracellular Matrix; IHC: Immunohistochemical; MIBC: Muscle invasive bladder cancer; NMIBC: Non-muscle invasive bladder cancer; RC: Radical cystectomy; TN-C:Tenascin-C;TURBT:Transurethral bladder tumor resection.
\end{abstract}

\section{Supplementary Information}

The online version contains supplementary material available at https://doi. org/10.1186/s12885-022-09285-X.

\section{Additional file 1.}

\section{Acknowledgements}

We thank Professor Jer-Tsong Hsieh for the gift of $253 \mathrm{~J}$ cell line.

\section{Authors' contributions}

ZF G was involved in the conceptualization, methodology, validation, writing, and reviewing and editing of the manuscript, as well as in visualization, supervision, project administration and funding acquisition. Y S was involved in formal analysis and investigation and in providing resources. L M was involved in data curation and methodology. YZ J was involved in data curation, in the writing of the original draft, and in study methodology. JH F was involved in the conceptualization, validation, writing, reviewing and editing of the manuscript, and in funding acquisition. All of the authors confirm the authenticity of all the raw data, and all authors have read \& approved the manuscript, and ensure that this is the case.

\section{Funding}

The present study was supported by the National Natural Science Foundation of China (grant no. 81572520) and the Shaanxi Provincial People's Hospital Incubation Fund Project (grant no. 2018YXQ-03). Data collection, including the patients-follow-up, survival analysis, cell molecular biology and signal pathway related experiment, supplemented by data analyzing for this paper was supported by 81572520 ; Immunohistochemical staining for tumor sections and the writing the manuscript was supported by 2018YXQ-03;

\section{Availability of data and materials}

All data generated or analyzed during this study are included in this published article (and its supplementary information files).

\section{Declarations}

\section{Ethics approval and consent to participate}

The present study was approved by the Ethics Committee of Xi'an Jiaotong University and all patients involved in the present investigation had signed informed consent forms.

\section{Consent for publication \\ Not applicable.}

\section{Competing interests}

The authors declare that they have no competing interests

\section{Author details}

'Department of Urology, Shaanxi Provincial People's Hospital, Xi'an 710068, China. ${ }^{2}$ Department of Urology, The First Affiliated Hospital of Xi'an Jiaotong University, 277 Yanta West Road, Xi'an 710061, People's Republic of China. ${ }^{3}$ Department of B ultrasound, Shaanxi Provincial People's Hospital, Xi'an 710068, China.
Received: 12 October 2021 Accepted: 9 February 2022

Published online: 04 March 2022

\section{References}

1. Sung H, Ferlay J, Siegel RL, Laversanne M, Soerjomataram I, Jemal A, et al. Global cancer statistics 2020: GLOBOCAN estimates of incidence and mortality worldwide for 36 cancers in 185 countries. CA Cancer J Clin. 2021;71(3):209-49.

2. Lenis AT, Lec PM, Chamie K, Mshs MD. Bladder Cancer: A Review. JAMA. 2020;324(19):1980-91.

3. Patel VG, Oh WK, Galsky MD. Treatment of muscle-invasive and advanced bladder cancer in 2020. CA Cancer J Clin. 2020;70(5):404-23.

4. Meng MV, Gschwend JE, Shore N, Grossfeld GD, Mostafid H, Black PC. Emerging Immunotherapy Options for bacillus Calmette-Guérin Unresponsive Nonmuscle Invasive Bladder Cancer. J Urol. 2019;202(6):1111-9.

5. Wu XR. Urothelial tumorigenesis: a tale of divergent pathways. Nat Rev Cancer. 2005;5(9):713-25.

6. Siracusano S, Rizzetto R, Porcaro AB. Bladder cancer genomics. Urologia. 2020;87(2):49-56.

7. Lv J, Zhu Y, Ji A, Zhang Q, Liao G. Mining TCGA database for tumor mutation burden and their clinical significance in bladder cancer. Biosci Rep. 2020;40(4):BSR20194337. https://doi.org/10.1042/BSR20194337.

8. de Vries RR, Nieuwenhuijzen JA, Vincent A, van Tinteren $\mathrm{H}$, Horenblas S. Survival after cystectomy for invasive bladder cancer. Eur J Surg Oncol. 2010;36(3):292-7.

9. Taddei ML, Giannoni E, Comito G, Chiarugi P. Microenvironment and tumor cell plasticity: an easy way out. Cancer Lett. 2013;341(1):80-96.

10. Lim YZ, South AP. Tumour-stroma crosstalk in the development of squamous cell carcinoma. Int J Biochem Cell Biol. 2014;53(0):450-8.

11. Cortez E, Roswall P, Pietras K. Functional subsets of mesenchymal cell types in the tumor microenvironment. Semin Cancer Biol. 2014;25:3-9. https://doi.org/10.1016/j.semcancer.2013.12.010.

12. Ribatti D, Moschetta M, Vacca A. Microenvironment and multiple myeloma spread. Thromb Res. 2014;133 Suppl 2(0):S102-6.

13. Yang X, Zhang X, Fu ML, Weichselbaum RR, Gajewski TF, Guo Y, et al. Targeting the Tumor Microenvironment with Interferon- $\beta$ Bridges Innate and Adaptive Immune Responses. Cancer Cell. 2014;25(1):37-48.

14. Curry JM, Sprandio J, Cognetti D, Luginbuhl A, Bar-ad V, Pribitkin E, et al. Tumor Microenvironment in Head and Neck Squamous Cell Carcinoma. Semin Oncol. 2014;41(2):217-34.

15. Orend G, Chiquet-Ehrismann R. Tenascin-C induced signaling in cancer. Cancer Lett. 2006;244(2):143-63.

16. Yalcin F, Dzaye O, Xia S. Tenascin-C Function in Glioma: Immunomodulation and Beyond. Adv Exp Med Biol. 2020;1272:149-72.

17. Wawrzyniak D, Grabowska M, Głodowicz P, Kuczyński K, Kuczyńska B, Fedoruk-Wyszomirska A, et al. Down-regulation of tenascin-C inhibits breast cancer cells development by cell growth, migration, and adhesion impairment. PLoS One. 2020;15(8):e237889.

18. Mishra P, Kiebish MA, Cullen J, Srinivasan A, Patterson A, Sarangarajan $\mathrm{R}$, et al. Genomic alterations of Tenascin $\mathrm{C}$ in highly aggressive prostate cancer: a meta-analysis. Genes Cancer. 2019;10(5-6):150-9.

19. Steiner F, Hauser-Kronberger C, Rendl G, Rodrigues M, Pirich C. Expression of Tenascin C, EGFR, E-Cadherin, and TTF-1 in Medullary Thyroid Carcinoma and the Correlation with RET Mutation Status. Int J Mol Sci. 2016;17(7):1093. https://doi.org/10.3390/ijms17071093.

20. Modica C, Olivero M, Zuppini F, Milan M, Basilico C, Vigna E. HGF/MET Axis Induces Tumor Secretion of Tenascin- $\mathrm{C}$ and Promotes Stromal Rewiring in Pancreatic Cancer. Cancers (Basel). 2021;13(14):3519. https://doi.org/10. 3390/cancers13143519.

21. Planska D, Kovalska J, Cizkova J, Horak V. Tissue Rebuilding During Spontaneous Regression of Melanoma in the Melanoma-bearing Libechov Minipig. Anticancer Res. 2018;38(8):4629-36.

22. Qi W, Yang Z, Li H, Cui Y, Xuan Y. The role of Tenascin- $C$ and Twist1 in gastric cancer: cancer progression and prognosis. APMIS. 2019;127(2):64-71.

23. Sun Z, Schwenzer A, Rupp T, Murdamoothoo D, Vegliante R, Lefebvre O, et al. Tenascin-C Promotes Tumor Cell Migration and Metastasis through Integrin a9ß1-Mediated YAP Inhibition. Cancer Res. 2018;78(4):950-61. 
24. Chung CY, Erickson HP. Cell surface annexin II is a high affinity receptor for the alternatively spliced segment of tenascin-C. J Cell Biol. 1994;126(2):539-48.

25. Hagiwara K, Harimoto N, Yokobori T, Muranushi R, Hoshino K, Gantumur D, et al. High Co-expression of Large Tenascin C Splice Variants in Stromal Tissue and Annexin A2 in Cancer Cell Membranes is Associated with Poor Prognosis in Pancreatic Cancer. Ann Surg Oncol. 2020;27(3):924-30.

26. Okina E, Manon-Jensen T, Whiteford JR, Couchman JR. Syndecan proteoglycan contributions to cytoskeletal organization and contractility. Scand J Med Sci Spor. 2009;19(4):479-89.

27. Multhaupt HA, Yoneda A, Whiteford JR, Oh ES, Lee W, Couchman JR. Syndecan signaling: when, where and why? J Physiol Pharmacol. 2009;60(Suppl 4):31-8.

28. Morgan MR, Humphries MJ, Bass MD. Synergistic control of cell adhesion by integrins and syndecans. Nat Rev Mol Cell Bio. 2007;8(12):957-69.

29. Koo BK, Jung YS, Shin J, Han I, Mortier E, Zimmermann P, et al. Structural basis of syndecan-4 phosphorylation as a molecular switch to regulate signaling. J Mol Biol. 2006;355(4):651-63.

30. Chung CY, Murphy-Ullrich JE, Erickson HP. Mitogenesis, cell migration, and loss of focal adhesions induced by tenascin-C interacting with its cell surface receptor, annexin II. Mol Biol Cell. 1996;7(6):883-92.

31. Murphy-Ullrich JE, Lightner VA, Aukhil I, Yan YZ, Erickson HP, Hook M. Focal adhesion integrity is downregulated by the alternatively spliced domain of human tenascin. J Cell Biol. 1991;115(4):1127-36.

32. Midwood K, Sacre S, Piccinini AM, Inglis J, Trebaul A, Chan E, et al. Tenascin- $C$ is an endogenous activator of Toll-like receptor 4 that is essential for maintaining inflammation in arthritic joint disease. Nat Med. 2009;15(7):774-80.

33. Fukunaga-Kalabis M, Martinez G, Nguyen TK, Kim D, Santiago-Walker A, Roesch A, et al. Tenascin-C promotes melanoma progression by maintaining the ABCB5-positive side population. Oncogene. 2010;29(46):6115-24.

34. Fujimoto D, Hirono Y, Goi T, Katayama K, Matsukawa S, Yamaguchi A. The activation of Proteinase-Activated Receptor-1 (PAR1) mediates gastric cancer cell proliferation and invasion. BMC Cancer. 2010;10:443.

35. Morgan MR, Hamidi H, Bass MD, Warwood S, Ballestrem C, Humphries MJ. Syndecan-4 phosphorylation is a control point for integrin recycling. Dev Cell. 2013;24(5):472-85.

36. Elfenbein A, Simons M. Syndecan-4 signaling at a glance. J Cell Sci. 2013;126(Pt 17):3799-804

37. McKean DM, Sisbarro L, Ilic D, Kaplan-Alburquerque N, Nemenoff $R$, Weiser-Evans M, et al. FAK induces expression of Prx1 to promote tenascin-C-dependent fibroblast migration. J Cell Biol. 2003;161(2):393-402.

38. Ghosh G, Wang VY, Huang DB, Fusco A. NF-kappaB regulation: lessons from structures. Immunol Rev. 2012;246(1):36-58.

39. Julien S, Puig I, Caretti E, Bonaventure J, Nelles L, van Roy F, et al. Activation of NF-kappaB by Akt upregulates Snail expression and induces epithelium mesenchyme transition. Oncogene. 2007;26(53):7445-56.

40. Li F, Zhang J, Arfuso F, Chinnathambi A, Zayed ME, Alharbi SA, et al. NFkappaB in cancer therapy. Arch Toxicol. 2015;89(5):711-31.

41. Jing Y, Han Z, Zhang S, Liu Y, Wei L. Epithelial-Mesenchymal Transition in tumor microenvironment. Cell Biosci. 2011;1:29.

42. Ouyang G, Wang Z, Fang X, Liu J, Yang CJ. Molecular signaling of the epithelial to mesenchymal transition in generating and maintaining cancer stem cells. Cell Mol Life Sci. 2010;67(15):2605-18.

43. Guan Z, Zeng J, Wang Z, Xie H, Lv C, Ma Z, et al. Urine tenascinC is an independent risk factor for bladder cancer patients. Mol Med Rep. 2014;9(3):961-6.

44. Gecks T, Junker K, Franz M, Richter P, Walther M, Voigt A, et al. B domain containing Tenascin-C: a new urine marker for surveillance of patients with urothelial carcinoma of the urinary bladder? Clin Chim Acta. 2011;412(21-22):1931-6.

45. Richter $\mathrm{P}$, Tost $\mathrm{M}$, Franz $\mathrm{M}$, Altendorf-Hofmann $\mathrm{A}$, Junker $\mathrm{K}$, Borsi $\mathrm{L}$, et al. $B$ and $C$ domain containing tenascin-C: urinary markers for invasiveness of urothelial carcinoma of the urinary bladder? J Cancer Res Clin. 2009;135(10):1351-8.

46. Berndt A, Anger K, Richter P, Borsi L, Brack S, Silacci M, et al. Differential expression of tenascin-C splicing domains in urothelial carcinomas of the urinary bladder. J Cancer Res Clin Oncol. 2006;132(8):537-46.

47. Weber CE, Kuo PC. The tumor microenvironment. Surg Oncol. 2012;21(3):172-7
48. Pantuck AJ, An J, Liu H, Rettig MB. NF-kappaB-dependent plasticity of the epithelial to mesenchymal transition induced by Von Hippel-Lindau inactivation in renal cell carcinomas. Cancer Res. 2010;70(2):752-61.

49. Midwood KS, Orend G. The role of tenascin- $C$ in tissue injury and tumorigenesis. J Cell Commun Signal. 2009;3(3-4):287-310.

50. Fang LY, Izumi K, Lai KP, Liang L, Li L, Miyamoto H, et al. Infiltrating macrophages promote prostate tumorigenesis via modulating androgen receptor-mediated CCL4-STAT3 signaling. Cancer Res. 2013;73(18):5633-46

51. Wunderlich H, Berndt A, Anger K, Gajda M, Borsi L, Brack S, et al. A1 and D domain of tenascin $C$ - New prognostic marker in bladder cancer. J Urology. 2008;179(4):315.

52. Bass MD, Humphries MJ. Cytoplasmic interactions of syndecan-4 orchestrate adhesion receptor and growth factor receptor signalling. Biochem J. 2002;368(Pt 1):1-15.

53. Guan Z, Ding C, Du Y, Zhang K, Zhu JN, Zhang T, et al. HAF drives the switch of HIF-1alpha to HIF-2alpha by activating the NF-kappaB pathway, leading to malignant behavior of T24 bladder cancer cells. Int J Oncol. 2014:44(2):393-402

\section{Publisher's Note}

Springer Nature remains neutral with regard to jurisdictional claims in published maps and institutional affiliations.
Ready to submit your research? Choose BMC and benefit from:

- fast, convenient online submission

- thorough peer review by experienced researchers in your field

- rapid publication on acceptance

- support for research data, including large and complex data types

- gold Open Access which fosters wider collaboration and increased citations

- maximum visibility for your research: over $100 \mathrm{M}$ website views per year

At BMC, research is always in progress.

Learn more biomedcentral.com/submissions 